\title{
Note
}

\section{Angiotensin I-Converting Enzyme (ACE) Inhibitory Activity of Ursolic Acid Isolated from Thymus vulgaris, $\mathrm{L}$.}

\author{
Atsumi SHIMADA ${ }^{1, *}$ and Masanori INAGAKI ${ }^{2}$ \\ ${ }^{1}$ Department of Nutritional Science, Faculty of Human Ecology, Yasuda Women's University, Asaminami, Hiroshima 731- \\ 0153, Japan. \\ ${ }^{2}$ Department of Pharmaceutical Chemistry, Faculty of Pharmacy, Yasuda Women's University, Asaminami, Hiroshima 731 - \\ 0153, Japan.
}

Received December 19, 2013 ; Accepted January 28, 2014

Thymus vulgaris L. (Thyme) is an aromatic medicinal herb widely used in folk medicine, as a food seasoning and herbal tea, and as an essential oil. A $70 \%$ EtOH extract from the leaves of thyme was prepared and a component was purified and characterized using an in vitro bio-assay based on the inhibition of angiotensin I-converting enzyme (ACE). Ursolic acid (1), a known pentacyclic triterpene acid, was isolated from the leaves of thyme and its structure was characterized by ${ }^{1} \mathrm{H},{ }^{13} \mathrm{C}-\mathrm{NMR}$ and $2 \mathrm{D}$ NMR spectroscopy, and by mass spectroscopy. Compound 1 showed an $I_{50}$ value of $3.05 \mathrm{mM}$. This is the first study to report the ACE inhibitory activity of 1.

Keywords: ACE inhibitor, ursolic acid, thymus vulgaris, L.

\section{Introduction}

Hypertension is one of the most common worldwide diseases and is considered to be a central factor in strokes and heart attacks attributed to untreated high blood pressure. The inhibition of angiotensin I-converting enzyme (ACE) (EC 3.4.15.1) is an important therapeutic target in the treatment of hypertension and cardiac failure. ACE plays an important role in the regulation of blood pressure. This regulation is mediated by the enzyme cascade of the renin-angiotensin system (RAS). ACE removes histidylleucine from angiotensin I to form the potent vasoconstricting octapeptide, angiotensin II, which is responsible for triggering vasoconstrictive effects. Angiotensin II also stimulates the secretion of aldosterone, which increases blood pressure by promoting the retention of sodium and water. In addition, ACE degrades the nonapeptide, bradykinin, which is a potent vasodilator (Hansen et al., 1996a and 1996b). ACE inhibitors could be valuable for the prevention of hypertension, and these inhibitors are in fact frequently used in therapy to reduce the morbidity and mortality of patients with hypertension (Hou et al., 2003; Tundis et $a l ., 2013)$. The inhibition of ACE is an effective screening method for identifying new antihypertensive agents (Lacaille-Dubois et al., 2001).

Thymus vulgaris L. (Thyme) belongs to the Lamiacea family, which is composed primarily of thyme, basil, oregano, rosemary, and sage. Thyme is an aromatic medicinal herb native to the Mediterranean region and is widely used in folk medicine, as a food seasoning, as a herbal tea, and as an essential oil. Thyme shows many activities, including antioxidant, antibacterial, antifungal, antileishmanial, anti-inflammatory, antispasmodic, immunomodulatory, and anticancer activity against the Hela cell line (Cerda et al., 2013; Durgadevi and Kalava, 2013). Our investigation of the metabolites of this herb led to the isolation of ursolic acid (1) as an ACE inhibitor. In this study, we describe the isolation of $\mathbf{1}$ from hydroethanolic extracts of thyme leaves, and the structural identification and the ACE inhibitory activity of $\mathbf{1}$. 


\section{Material and Methods}

General experimental procedures Melting points were determined using a Yanaco MP-S3 micromelting point apparatus (Kyoto, Japan). Optical rotation data were determined with a Horiba SEPA-200 polarimeter (Kyoto, Japan). The ${ }^{1} \mathrm{H}-\mathrm{NMR}$ and ${ }^{13} \mathrm{C}$ NMR spectra were recorded using a Bruker AVANCE ${ }^{\mathrm{TM}}$ III 600 (Karlsruhe, Germany). EI-MS spectra were recorded using a Shimadzu GCMS-QP2010 Plus mass spectrometer (Kyoto, Japan). Silica gel [Wako Pure Chemical Industries, Ltd (Osaka, Japan); $75-150 \mu \mathrm{m}]$ was used for column chromatography.

Chemicals Air-dried leaves of T. vulgaris L. were purchased from Jewel Colours Japan PT Lab. Co., Ltd (Tokyo, Japan). Apigenin, dimethylsulfoxide, hippuryl-L-histidyl-L-leucine (HipHis-Leu), rosmarinic acid, and 2,4,6-trinitrobenzene sulfonate (TNBS) were purchased from Wako Pure Chemical Industries, Ltd. Rabbit lung angiotensin I-converting enzyme (EC 3.4.15.1) was purchased from Sigma-Aldrich Co. (St. Louis, USA). Apigenin and rosmarinic acid were used as positive controls as they had previously been reported to show ACE inhibitory activity (Li et al., 2008; Shukor et al., 2013).

Extraction and isolation The leaves of T. vulgaris L. (300 g) were extracted twice with $70 \% \mathrm{EtOH}$. The combined extracts were concentrated in vacuo and then partitioned repeatedly with a sequence of $n$-hexane, EtOAc, $n$-butanol, and distilled water. A concentrated $n$-hexane fraction $(6.14 \mathrm{~g})$, EtOAc fraction $(7.99 \mathrm{~g})$, $n$-butanol fraction $(0.50 \mathrm{~g})$, and distilled water fraction $(4.13 \mathrm{~g})$ were obtained. The EtOAc fraction was loaded onto a silica gel column and eluted with $\mathrm{CHCl}_{3} / \mathrm{MeOH}$. The fraction $(2.10 \mathrm{~g})$ obtained by eluting with $3 \% \mathrm{MeOH}$ was fractionated for a second time by column chromatography on silica gel ( $n$-hexane/acetone). The fraction $(460 \mathrm{mg}$ ) obtained by eluting with $50 \%$ acetone was further fractionated for a third time by column chromatography on silica gel ( $n$-hexane/EtOAc). The fraction $(155 \mathrm{mg})$ obtained by eluting with $30 \%$ EtOAc was recrystallized from acetone to yield $26.1 \mathrm{mg}$ of compound 1 as a colorless amorphous solid.

Compound 1 (ursolic acid): Colorless amorphous solid. mp $238-240^{\circ} \mathrm{C} .[\alpha]_{\mathrm{D}}=+72.1^{\circ}(c=0.1$, EtOH $) .{ }^{1} \mathrm{H} \mathrm{NMR}(600 \mathrm{MHz}$, DMSO- $\left.d_{6}\right): \delta 0.67(1 \mathrm{H}, \mathrm{m}, 5-\mathrm{H}), 0.69(3 \mathrm{H}, \mathrm{s}, 25-\mathrm{H}), 0.73(3 \mathrm{H}, \mathrm{s}$, 24-H), 0.76 (3H, s, 26-H), $0.82(3 \mathrm{H}, \mathrm{d}, J=6.5 \mathrm{~Hz}, 29-\mathrm{H}), 0.85(2 \mathrm{H}$, m, 7-H), 0.86 (2H, m, 16-H), 0.88 (3H, d, $J=6.3 \mathrm{~Hz}, 30-\mathrm{H}), 0.90$ $(3 \mathrm{H}, \mathrm{s}, 23-\mathrm{H}), 0.92(1 \mathrm{H}, \mathrm{m}, 19-\mathrm{H}), 0.95(1 \mathrm{H}, \mathrm{m}, 20-\mathrm{H}), 1.00(2 \mathrm{H}$, ddd, $J=13.0,4.9,2.4 \mathrm{~Hz}, 2-\mathrm{H}), 1.05(3 \mathrm{H}, \mathrm{s}, 27-\mathrm{H}), 1.29(1 \mathrm{H}, \mathrm{m}$, 21-H), 1.49 (8H, m, 1-H, 6-H, 9-H, 15-H, 21-H), 1.61(2H, m, 22H), $1.88(2 \mathrm{H}, \mathrm{m}, 11-\mathrm{H}), 2.12(1 \mathrm{H}, \mathrm{d}, J=5.8 \mathrm{~Hz}, 18-\mathrm{H}), 3.00(1 \mathrm{H}, \mathrm{m}$, $3-\mathrm{H}), 5.15(1 \mathrm{H}, \mathrm{d}, J=4.9 \mathrm{~Hz}, 12-\mathrm{H}) .{ }^{13} \mathrm{C}$ NMR $(150 \mathrm{MHz}$, DMSO- $\left.d_{6}\right): \delta 15.2$ (q, C-25), 16.0 (q, C-26), 16.9(q, C-24), 17.0(q, C-29), 18.0(t, C-6), 21.0 (q, C-23), 22.8 (t, C-11), 23.2 (q, C-27), 23.8 (t, C-16), 27.0(t, C-15), 27.5 (t, C-2), 28.2 (q, C-30), 32.7(t, C-21), 32.8(t, C-7), 36.3(s, C-10), 36.5 (t, C-22), 38.2 (s, C-8), 38.3 (t, C-1), 38.4 (d, C-19), 38.5 (d, C-20), 38.8 (s, C-4), 41.6 (s, C-14), 46.8 (d, C-9), 47.0(s, C-17), 52.3 (d, C-18), 54.7(d, C-5),
76.8 (d, C-3), 124.5 (d, C-12), 138.2 (s, C-13), 178.3 (s, C-28). MS (EI): $m / z(\%)=456(2)\left[\mathrm{M}^{+}\right], 248(92), 203(40), 133(33), 57(88)$, 43 (100).

ACE inhibitory assay ACE inhibitory activity was assayed according to the method of Matsui et al. (1992). A mixture containing $0.03 \mathrm{~mL}$ of sample solution in $5 \%$ dimethylsulfoxide, $0.1 \mathrm{~mL}$ of $0.06 \mathrm{U} / \mathrm{mL} \mathrm{ACE}$, and $0.25 \mathrm{~mL}$ of $7.6 \mathrm{mM}$ Hip-His-Leu in borate buffer ( $\mathrm{pH} 8.3$ ) containing $200 \mathrm{mM} \mathrm{NaCl}$ was incubated at $37^{\circ} \mathrm{C}$ for $30 \mathrm{~min}$. The reaction was stopped by the addition of $0.25 \mathrm{~mL}$ of $0.5 \mathrm{M} \mathrm{HCl}$, then the solution was adjusted to $\mathrm{pH} 9.12$ by adding $0.2 \mathrm{~mL}$ of Kolthoff buffer $\left[0.1 \mathrm{M} \mathrm{Na}_{2} \mathrm{HPO}_{4}-1.0 \mathrm{M}\right.$ $\mathrm{NaOH}(1: 2)$ ], followed by $0.025 \mathrm{~mL}$ of $0.1 \mathrm{M}$ TNBS in $0.1 \mathrm{M}$ $\mathrm{Na}_{2} \mathrm{HPO}_{4}$. After the mixture was incubated at $37^{\circ} \mathrm{C}$ for $20 \mathrm{~min}$, $4.5 \mathrm{~mL}$ of $4 \mathrm{mM} \mathrm{Na}_{2} \mathrm{SO}_{3}$ in $0.2 \mathrm{M} \mathrm{NaH}_{2} \mathrm{PO}_{4}$ was added and the absorbance was measured at $416 \mathrm{~nm}$ with a Hitachi (Tokyo, Japan) U-1800 spectrophotometer. The percent inhibition of ACE activity was calculated according to the following equation: the inhibitory

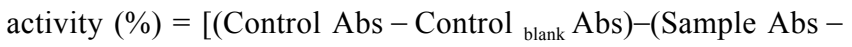
Sample $_{\text {blank }}$ Abs)] / (Control Abs - Control blank Abs) X 100, where control is the activity of the enzyme with added distilled water instead of sample solution and blank is the activity without the enzyme. The ACE inhibitor concentration required to inhibit 50\% of the ACE activity under the assayed conditions was defined as the $\mathrm{IC}_{50}$ value. All experiments were performed in triplicate.

\section{Results and Discussion}

The hydroethanolic extracts of the leaves of T. vulgaris L. inhibited ACE activity by $36 \%$ at a concentration of $10 \mathrm{mg} / \mathrm{mL}$. A component in the extract was purified by solvent partition, silica gel column chromatography and recrystallization to afford compound $\mathbf{1}$.

Structural characterization was carried out using a combination of $1 \mathrm{D}{ }^{1} \mathrm{H},{ }^{13} \mathrm{C}$, DEPT, and HSQC experiments. Compound 1 was obtained as a colorless amorphous solid with $\mathrm{mp}$ of $238-240^{\circ} \mathrm{C}$ and an optical rotation of $+72.1^{\circ}(c=0.1$, EtOH $)$. The ${ }^{13} \mathrm{C}$ - and ${ }^{1} \mathrm{H}-\mathrm{NMR}$ spectra of $\mathbf{1}$ indicated the presence of seven methyl carbons, nine aliphatic methylene carbons, six aliphatic methine carbons, five quaternary carbons, two $\mathrm{sp}^{2}$ carbons, and one carbonyl carbon. In the mass spectrum, fragments were observed at $m / z 248\left(\mathrm{C}_{16} \mathrm{H}_{24} \mathrm{O}_{2}\right), 203\left(\mathrm{C}_{15} \mathrm{H}_{23}\right)$, and $133\left(\mathrm{C}_{10} \mathrm{H}_{13}\right)$, which are derived from the retro-Diels-Alder cleavages of the amyrin skeleton (Budzikiewicz et al., 1963). All these data showed that 1 belongs to the ursane series of triterpenoids (Siddiqui et al., 1986). Two aliphatic methine signals at $\delta 38.4$ (C-19) and 38.5 (C-20) in the ${ }^{13} \mathrm{C}$-NMR spectrum, and two coupling constants of $6.5 \mathrm{~Hz}(29-$ $\mathrm{H})$ and $6.3 \mathrm{~Hz}(30-\mathrm{H})$ in the ${ }^{1} \mathrm{H}-\mathrm{NMR}$ spectrum, indicated the presence of a $-\mathrm{CH}\left(\mathrm{CH}_{3}\right)-\mathrm{CH}\left(\mathrm{CH}_{3}\right)$ - system. Compound 1 was identified as ursolic acid (3 $\beta$-hydroxy-urs-12-en-28-oic-acid) by comparing its physicochemical properties with those reported earlier (Seebacher et al., 2003; Taketa et al., 2004; Gnoatto et al., 2008) (Fig. 1). 


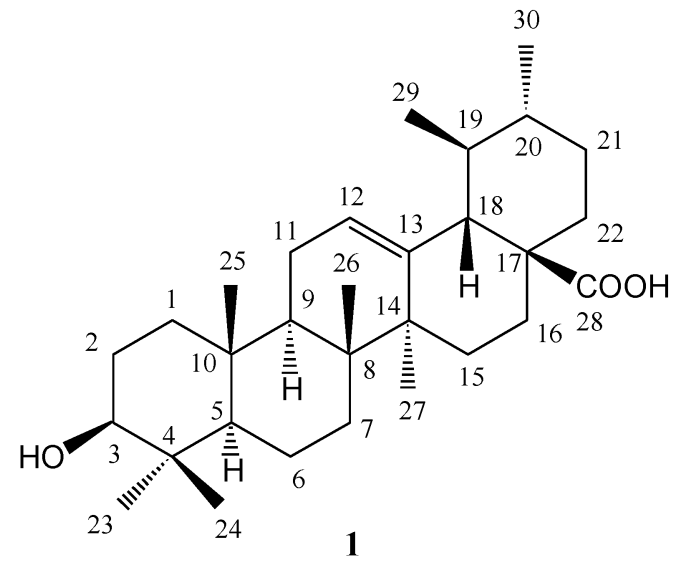

Fig. 1. Structure of 1

Compound $\mathbf{1}$ is a natural pentacyclic triterpene acid widely present in many plant species such as Calluna vulgaris, Eribotrya japonica L., Eucalyptus hybrid, Glechoma hederacea L., Melaleuca leucadendron L., Ocimum canctum L., Rosmarinus officinalis L., Pyrola rotundifolia, Psychotria serpens L., Sambucus chinesis L., Solanum incanum L., and Tripterospermum taiwanense (Liu, 1995), as well as Thymus species (Ismaili et al., 2004; Janicsak et al., 2006; Özgen et al., 2011; Gordo et al., 2012). It has been reported that fairly high concentrations of $\mathbf{1}$ are found in $T$. vulgaris L. (0.643\% dry weight) (Janicsák et al., 2006) and dried cranberry (0.659\%) (Zhang et al., 2013). The concentration of 1 ranged from trace amounts to $4.019 \%$ in 88 taxa of the Lamiacea family (Janicsák et al., 2006). Among natural products, the terpenoids represent a unique and most important class of bioactive compounds. Compound $\mathbf{1}$ exhibits biological and pharmacological properties, including antioxidant, anti-inflammatory, antihyperlipidemia, hepatoprotective, anticancer, and antimicrobial activities combined with low toxicity, and is often used in the folk medicines of many Asian countries (Liu, 1995; Zhang et al., 2006; Gnoatto et al., 2008; Jäger et al., 2009). Additionally, 1 has been recommended for use in cancer therapy in Japan, and cosmetic preparations containing $\mathbf{1}$ have been patented in Japan for the prevention of skin cancer (Muto et al., 1990; Ishida et al., 1990). However, there is no information regarding the ACE inhibitory activity of $\mathbf{1}$.

Compound 1, apigenin, and rosmarinic acid used as a positive control were examined for their effects on rabbit lung ACE. The $\mathrm{IC}_{50}$ values of 1 , apigenin, and rosmarinic acid were $3.05 \mathrm{mM}$, $2.93 \mathrm{mM}$, and $1.67 \mathrm{mM}$, respectively

(Table 1). The ACE inhibitory activity of $\mathbf{1}$ was weaker than that of rosmarinic acid, but similar to that of apigenin. ACE is a dipeptidyl carboxypeptidase in which the catalytic zinc ion is bound to the protein by a $\mathrm{His}_{2}$ Glu motif. ACE removes histidyl-leucine from angiotensin I to form the physiologically active octapeptide, angiotensin II, a potent vasoconstrictor that inactivates the vasodilating nonapeptide, bradykinin. The hydroxy groups of apigenin and the hydroxy groups and/or the carboxy group of
Table 1. $\mathrm{IC}_{50}$ value of $\mathbf{1}$, apigenin and rosmarinic acid

\begin{tabular}{lc}
\hline Compound & $\mathrm{IC}_{50}(\mathrm{mM})$ \\
\hline $\mathbf{1}$ & $3.05^{\mathrm{b}}$ \\
Apigenin & $2.93^{\mathrm{b}}$ \\
Rosmarinic acid & $1.67^{\mathrm{a}}$
\end{tabular}

Means with same letter are not significantly different $(P<0.05$, Duncan's multiple-range test).

rosmarinic acid might bind to the catalytic zinc ion present at the active centre of ACE. These functional groups appear to increase the potency to inhibit ACE (Li et al., 2008; Shukor et al., 2013; Day and Cohen, 2013). From our results and the inhibitory activities of 1 against aromatase and protein tyrosine phosphatase $1 \mathrm{~B}$, it appears that the carboxy group at $\mathrm{C}-17$ and/or the hydroxy group at $\mathrm{C}-3$ of $\mathbf{1}$ is required for $\mathrm{ACE}$ inhibition, since these functional groups might bind to the catalytically functional zinc ion in the active centre of ACE (Zhang et al., 2006; Gnoatto et al., 2008; Tundis et al., 2013). However, the ursane-type triterpenoidal skeleton of $\mathbf{1}$ might contribute to reduce ACE inhibitory activity. This is the first report of the ACE inhibitory activity of $\mathbf{1}$.

\section{References}

Budzikiewicz, H., Wilson, J.M., and Djerassi, C. (1963). Mass spectrometry in structural and stereochemical problems. XXXII. Pentacyclic triterpenes. J. Am. Chem. Soc., 85, 3688-3699.

Cerda, A., Martinez, M.E., Soto, C., Poirrier, P., Perez-Correa, J.R., Vergara-Salinas, J.R., and Zuniga, M.E. (2013). The enhancement of antioxidant compounds extracted from Thymus vulgaris using enzymes and the effects of extracting solvent. Food Chem., 139, 138-143.

Day, J. A. and Cohen, S. M. (2013). Investigating the selectivity of metalloenzyme inhibitors. J. Med. Chem., 56, 7997-8007.

Durgadevi, P. and Kalava S.V. (2013). Investigation on the in vitro antioxidant, antimutagenic and cytotoxic potential of Thymus vulgaris $\mathrm{L}$. hydro-alcoholic extract. Int. J. Pharm. Sci. Res., 4, 3157-3164.

Gnoatto, S.C.B., Dassonville-Klimpt, A., Da Nascimento, S., Galéra P., Boumediene, K., Gosmann, G., Sonnet, P., and Moslemi, S. (2008). Evaluation of ursolic acid isolated from Ilex paraguariensis and derivatives on aromatase inhibition. Euro. J. Med. Chem., 43, 18651877.

Gordo, J., Maximo, P., Cabrita, E., Lourenco, A., Oliva, A., Almeida, J., Filipe, M., Cruz, P., Barcia, R., and Santos, M. (2012). Thymus mastichina: chemical constituents and their anti-cancer activity. Nat. Prod. Commun., 7, 1491-1494.

Hansen, K., Adsersen, A., Christensen, S.B., Jensen, S.R., Nyman, U., and Smitt U.W. (1996a). Angiotensin converting enzyme (ACE) inhibitory flavonoids from Erythroxylum laurifolium. Phytomedicine, 2, 313-317.

Hansen, K., Adsersen, A., Christensen, S.B., Jensen, S.R., Nyman, U., and Smitt U.W. (1996b). Isolation of an angiotensin converting enzyme (ACE) inhibitor from Olea europaea and Olea lancea. Phytomedicine, 2 , 319-325. 
Hou, W., Chen, H., and Lin, Y. (2003). Antioxidant peptides with angiotensin converting enzyme inhibitory activities and applications for angiotensin converting enzyme purification. J. Agric. Food Chem., 51, 1706-1709.

Ishida, M., Okubo, T., Koshimizu, K., Daito, H., Tokuda, H., Kin, T., Yamamoto, T., and Yamazaki, N. (1990). Topical preparations containing ursolic acid and/or oleanolic acid for prevention of skin cancer. Japan Kokai Tokkyo Koho, JP 02017121 A 19900122 (in Japanese).

Ismaili, H., Milella, L., Fkih-Tetouani, S., Ilidrissi, A., Camporese, A., Sosa, S., Altinier, G., Della Loggia R., and Aquino, R. (2004). In vivo topical anti-inflammatory and in vitro antioxidant activities of two extracts of Thymus satureioides leaves. J. Ethnopharmacol., 91, 31-36.

Jäger, S., Trojan, H., Kopp, T., Laszczyk, M.N., and Scheffler, A. (2009). Pentacyclic triterpene distribution in various plants-Rich sources for a new group of multi-potent plant extracts. Molecules, 14, 2016-2031.

Janicsák, G., Veres, K., Zoltan Kakasy, A., and Mathe, I. (2006). Study of the oleanolic and ursolic acid contents of some species of the Lamiaceae. Biochem. Systematics and Ecology, 34, 392-396.

Lacaille-Dubois, M.A., Franck, U., and Wagner, H. (2001). Search for potential angiotensin converting enzyme (ACE)-inhibitors from plants. Phytomedicine, 8, 47-52.

Li, Q., Li, B., Zhang, Y., Gao, X., Li, C., and Zhang, G. (2008). Three angiotensin-converting enzyme inhibitors from Rabdosia coetsa. Phymed., 15, 386-388.

Liu, J. (1995). Pharmacology of oleanolic acid and ursolic acid. $J$. Ethnopharmacol., 49, 57-68.

Matsui, T., Matsufuji, H., and Osajima, Y. (1992). Colorimetric measurement of angiotensin I-converting enzyme inhibitory activity with trinitrobenzene sulfonate. Biosci. Biotechnol. Biochem., 56, 517-518.
Muto, Y., Ninomiya, M., and Fujiki, H. (1990). Present status of research on cancer chemoprevention in Japan. Jpn. J. Clin. Oncol., 20, 219-224.

Özgen, U., Mavi, A., Terzi, Z., Kazaz C., Aşçı, A., Kaya, Y., and Seçen H. (2011). Relationship between chemical structure and antioxidant activity of luteolin and its glycosides isolated from Thymus sipyleus subsp. sipyleus var. sipyleus. Rec. Nat. Prod., 5, 12-21.

Seebacher, W., Simic, N., Weis, R., Saf, R., and Kunert, O. (2003). Spectral assignments and reference data. Magn. Reson. Chem., 41, 636-638.

Shukor, N. A., Van Camp, J., Gonzales, G.B., Staljanssens, D., Struijs, K., Zotti, M.J., Raes, K., and Smagghe, G. (2013). Angiotensin-converting enzyme inhibitory effects by plant phenolic compounds: A study of structure activity relationships. J. Agric. Food Chem., 61, 11832-11839.

Siddiqui, S., Hafeez, F., Begum, S., and Siddiqui, B.S. (1986). Kaneric acid, a new triterpene from the leaves of Nerium oleander. J. Nat. Prod., 49, 1086-1090.

Taketa, A.T.C., Breitmaier, E., and Schenkel, E.P. (2004). Triterpenes and triterpenoidal glycosides from the fruits of Ilex paraguariensis (Mate). J. Braz. Chem. Soc., 15, 205-211.

Tundis, R., Farsad, N., and Menichini, F. (2013). Angiotensin-converting enzyme inhibitory activity and antioxidant properties of Nepeta crassifolia Boiss \& Buhse and Nepeta binaludensis Jamzad. Phytother. Res., 27, 572-580.

Zhang, F., Daimaru, E., Ohnishi, M., Kinoshita, M., and Tokuji, Y. (2013). Oleanolic acid and ursolic acid in commercial dried fruits. Food Sci. Technol. Res., 19, 113-116.

Zhang, W., Hong, D., Zhou, Y., Zhang, Y., Shen, Q., Li, J., Hu, L., and Li, J. (2006). Ursolic acid and its derivative inhibit protein tyrosine phosphatase 1B, enhancing insulin receptor phosphorylation and stimulating glucose uptake. Biochim. Biophys. Acta, 1760, 1505-1512. 